\title{
Underpotential Deposition of Al-Ce Alloys at an Al Electrode from $\mathrm{LiCl}-\mathrm{KCl}-\mathrm{CeCl}_{3}$ Melts
}

\author{
Zhang Meng ${ }^{1,2}$, Li Yunna ${ }^{2}, \quad$ Han Wei $^{2}$, Zhang Milin ${ }^{2}, \quad$ Xue Yun ${ }^{1,2}, \quad$ Wang Yanli ${ }^{2}$, \\ Gao Yang ${ }^{1}$
}

${ }^{1}$ Fundamental Science on Nuclear Safety and Simulation Technology Laboratory, Harbin Engineering University, Harbin 150001, China; ${ }^{2}$ Key Laboratory of Superlight Materials and Surface Technology, Ministry of Education, Harbin Engineering University, Harbin 150001, China

\begin{abstract}
Electrochemical behavior of $\mathrm{Ce}(\mathrm{III})$ and underpotential deposition of $\mathrm{Al}-\mathrm{Ce}$ alloys were investigated at an $\mathrm{Al}$ active electrode in $\mathrm{LiCl}-\mathrm{KCl}-\mathrm{CeCl}_{3}$ melts. Compared with the cyclic voltammetry curves on a Mo electrode, the redox potential of $\mathrm{Ce}(\mathrm{III}) / \mathrm{Ce}$ at the $\mathrm{Al}$ electrode is more positive; there are two new plateaus between the deposition plateau of $\mathrm{Al}$ and $\mathrm{Ce}$ metal by open circuit chronopotentiometry, which means two kinds of intermetallic compounds. All above show Ce(III) forms intermetallic compound by underpotential deposition electrochemically. Furthermore, it is also confirmed by Al-Ce alloys, which are obtained at the $\mathrm{Al}$ active electrode in $\mathrm{LiCl}-\mathrm{KCl}-\mathrm{CeCl}_{3}$ melts after potentiostatic deposition under the same condition. The formation of AlCe and $\mathrm{AlCe}_{3}$ is illuminated by X-ray diffraction (XRD). The reasons of AlCe and $\mathrm{AlCe}_{3}$ formation were explained by XRD and phase diagram of Al-Ce. The standard Gibbs free energies of $\mathrm{AlCe}$ and $\mathrm{AlCe}_{3}$ formation were calculated by XRD and open circuit chronopotentiometry. The analysis of scanning electron microscopy (SEM) and energy dispersive spectrometry (EDS) reveals that cerium exists at the surface of $\mathrm{Al}$ electrode to form an Al-Ce alloys layer, which is about $28 \mu \mathrm{m}$ in thickness, and evenly coated the Al electrode.
\end{abstract}

Key words: $\mathrm{LiCl}-\mathrm{KCl}$ melts; underpotential deposition; $\mathrm{Al}$ electrode; $\mathrm{Al}-\mathrm{Ce}$ alloy

Compared with a traditional method of separation actinides (An) by hydrometallurgical process from fission products (FPs), pyrochemical reprocessing has been considered as a promising alternative due to its compactness, criticality control benefits, resistance to radiation effects, compatibility with advanced fuel types, and the ability to produce low purity products to prevent nuclear proliferation ${ }^{[1-3]}$. Because An and lanthanides (Ln) have similar chemical properties, it is an essential and challenging issue to efficient separation of An over $\mathrm{Ln}$ in FPs $^{[4-8]}$.

Since the operation conditions influence the efficiency of reprocess and the structure of the separation cell, it is important to know the electrochemical behaviors of An and Ln on different electrodes for the understanding of the process ${ }^{[9]}$. We use aluminum to recover An group metals according to the thermodynamic calculations to separate An from Ln efficiently ${ }^{[10-12]}$. The An have already been separated selectively by electrolysis on solid $\mathrm{Al}$ active cathodes in the $\mathrm{LiCl}-\mathrm{KCl}$ melts, and formed $\mathrm{An}-\mathrm{Al}$ alloys at the same time ${ }^{[13]}$.

In previous experiments, R. Malmbeck and co-workers have succeed in electrodeposition of U-Al alloys ${ }^{[14]}, \mathrm{Pu}-\mathrm{Al}$ alloys ${ }^{[15]}, \mathrm{U}-\mathrm{Pu}-\mathrm{Al}$ alloys ${ }^{[16]}$, and An-Al alloys ${ }^{[10]}$ on solid

Received date: August 14, 2015

Foundation item: High Technology Research and Development Program of China (2011AA03A409); National Natural Science Foundation of China (51104050, 91326113, 21271054, 21173060); Natural Science Foundation of Heilongjiang Province of China (E201413); China Postdoctoral Science Foundation (20110491029); Heilongjiang Postdoctoral Fund (LBH-Z10208); Heilongjiang Educational Commission Foundation (12513045); the Fundamental Research Funds for the Central Universities (HEUCF161501); the Scientific Technology Bureau of Harbin (2012RFQXS102); the Basic Research Foundation of Harbin Engineering University (HEUFT08031)

Corresponding author: Han Wei, Ph. D., Professor, Key Laboratory of Superlight Materials and Surface Technology, Ministry of Education, Harbin Engineering University, Harbin 150001, P. R. China, E-mail: happymeng1980@126.com 
Al cathodes in the LiCl-KCl melts. While, Y. Castrillejo and co-workers have succeed in extracting Pr, Dy, Gd, Er, $\mathrm{Ho}, \mathrm{Eu}, \mathrm{Lu}, \mathrm{Tm}, \mathrm{Yb}$ and $\mathrm{Sm}$ on the $\mathrm{Al}$ electrodes from molten chlorides in the form of Al-Ln alloys ${ }^{[17]}$.

Cerium is not only a typical element of the FPs, but also a surrogate for studying the behavior of uranium in molten salts ${ }^{[18,19]}$. Therefore, it is essential to study the electrochemical property of $\mathrm{Ce}(\mathrm{III})$ in $\mathrm{LiCl}-\mathrm{KCl}$ melts. On an inert electrode, several prior investigations have been conducted on the thermodynamic properties, kinetic reaction parameters and electrochemical behavior of $\mathrm{CeCl}_{3}$ in molten LiCl-KCl melts, such as the structure ${ }^{[20]}$, diffusion coefficient ${ }^{[21-23]}$, the standard potential ${ }^{[9,24-26]}$ and rate constant ${ }^{[19,27,28]}$. Compared with these data on an inert electrode, there are only a few reports on an Al cathode. Y. Castrillejo et al. reported the electrodeposition of Al-Ce alloys on Al cathode without XRD pattern analysis ${ }^{[29]}$. Furthermore, Ce can form intermetallic compound such as Al-Ce alloy with Al according to Al-Ce phase diagram ${ }^{[30,31]}$.

On the basis of these backgrounds, we propose to investigate the electrochemical behavior of $\mathrm{Ce}$ (III) by cyclic voltammetry and open circuit chronopotentiometry, and the formation of Al-Ce alloys on $\mathrm{Al}$ cathode in $\mathrm{LiCl}-\mathrm{KCl}$ melts. The results will help us to further study the cerium extraction from molten salts via electroreduction.

\section{Experiment}

The $\mathrm{LiCl}(99.0 \%)$ and $\mathrm{KCl}(99.5 \%)$ mixture with composition $\mathrm{LiCl}: \mathrm{KCl}=58.8: 41.2(\mathrm{~mol} \%)$ were melted in an alumina crucible (Volume $=150 \mathrm{~cm}^{3}$ ) and then dried by an electric tubular heater. The temperature of the mixture was measured with a nickel-chromium thermocouple which had an alumina scabbard. Water and metal ion impurities were removed by drying and pre-electrolysis. Anhydrous $\mathrm{CeCl}_{3}$ $(\geqslant 99.0 \%)$ powder was introduced into the bath in order to provide cerium ions. All experiments were carried out under a nitrogen atmosphere.

All electrochemical measurements were implemented by an Im6eX electrochemical workstation (Zahner Co., Ltd.) with a THALES 3.08 software package. The reference electrode was manufactured by immersing a silver wire $(d=0.5 \mathrm{~mm})$ into a quartz tube which contained a solution of $\mathrm{AgCl}(1 \mathrm{wt} \%)$ in $\mathrm{LiCl}-\mathrm{KCl}(58.8: 41.2, \mathrm{~mol} \%)$ melts. The working electrode was Mo wire ( $d=1 \mathrm{~mm}, 99.99 \%$ purity) or Al (99.99\% purity), which was polished thoroughly using $\mathrm{SiC}$ paper, and then placed in ethanol to clean by ultrasound. A spectrally pure graphite $\operatorname{rod}(d=6 \mathrm{~mm})$ was used as the counter electrode which was polished as the method mentioned before use. The active electrode surface was determined by measuring the immersion depth of the electrode in the melts at each time.

\section{Results and Discussion}

\subsection{Cyclic voltammetry}

Cyclic voltammogram (CV) of $\mathrm{LiCl}-\mathrm{KCl}-\mathrm{CeCl}_{3}$ melts at the Mo (curve 1, dotted line) and Al (curve 2, solid line) electrode is shown in Fig.1. The different electrochemical signals obtained at $\mathrm{Al}$ and Mo electrode are obvious. At the $\mathrm{Al}$ electrode, there are three cathodic peaks marked as $\mathrm{A}_{2}$, $\mathrm{B}_{2}$ and $\mathrm{C}_{2}$. The peaks $\mathrm{C}_{2}{ }^{\prime} / \mathrm{C}_{2}$ correspond to the $\mathrm{Al}$ oxidation/reduction, which have been pointed out by Wei ${ }^{[32]}$. The reduction potential value of $\mathrm{Li}^{+}$(peak $\mathrm{B}_{2}$ ) is more positive at the $\mathrm{Al}$ electrode than that at the Mo electrode (peak $\mathrm{B}_{1}$ ), which has also been observed by Castrillejo ${ }^{[29]}$.

The electrodeposition peak of $\mathrm{Ce}$ (III) on $\mathrm{Al}$ and $\mathrm{Mo}$ electrode is $A_{2}$ and $A_{1}$, respectively. The onset potential value of $\mathrm{A}_{2}$ is $-1.25 \mathrm{~V}$, which is more positive than the potential of $A_{1}(-1.78 \mathrm{~V})$. It is likely to be caused by the underpotential deposition (UPD) of cerium on aluminum substrate. During this process, $\mathrm{AlCe}_{x}$ alloys are formed according to Al-Ce phase diagram ${ }^{[30]}$, as the following reaction (1):

$$
x \mathrm{Ce}(\mathrm{III})+\mathrm{Al}+3 x \mathrm{e} \rightarrow \mathrm{AlCe}_{x}
$$

During the reverse scan, an anodic peak $\mathrm{A}_{2}{ }^{\prime}$ which corresponds to Ce dissolution from the $\mathrm{AlCe}_{x}$ is observed.

\subsection{Open circuit chronopotentiometry}

An EMF measurement was as follows: first, electrodeposition of $\mathrm{Ce}$ metal at the $\mathrm{Al}$ electrode by constant potential electrolysis was at $-2.20 \mathrm{~V}$ (vs. $\mathrm{Ag} / \mathrm{AgCl}$ ) for $10 \mathrm{~s}$ After that, a transient curve where the open-circuit potential was recorded versus time on $\mathrm{Al}$ electrode at $843 \mathrm{~K}$ is shown in Fig.2. At the beginning, the potential stays at around $-2.08 \mathrm{~V}$ (plateau 1), which is generated by pre-deposited Li metal on the electrode. Then, 4 potential plateaus (plateaus 2 5) are observed at $-1.91,-1.29,-1.14$ and $-0.95 \mathrm{~V}$, respectively. Among them, the plateaus 2 and 5 are interpreted as the pre-deposited $\mathrm{Ce}$ and $\mathrm{Al}$ metals, respectively. Since the deposited Ce metal reacts with Al

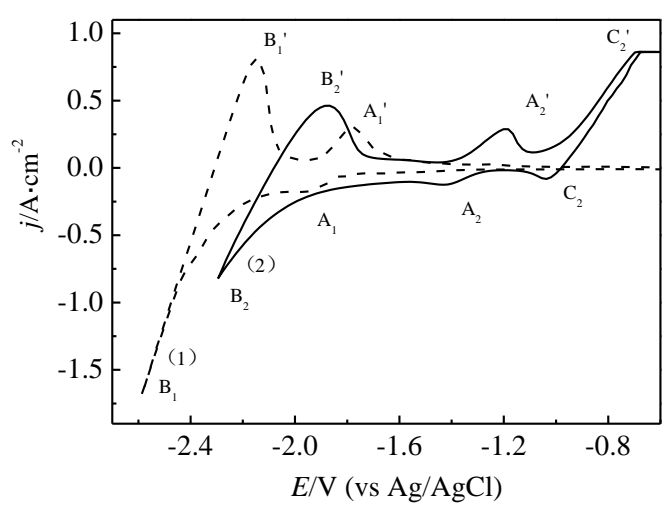

Fig.1 Curves of the LiCl-KCl melts containing $0.96 \times 10^{-4}$ $\mathrm{mol} \cdot \mathrm{cm}^{-3} \mathrm{CeCl}_{3}$ on a molybdenum electrode $(S=0.944$ $\left.\mathrm{cm}^{2}\right)$ (dotted curve) and on an Al electrode $\left(S=2.3 \mathrm{~cm}^{2}\right)$ (solid curve) at $843 \mathrm{~K}$ with a scan rate of $0.1 \mathrm{~V} \cdot \mathrm{s}^{-1}$ 


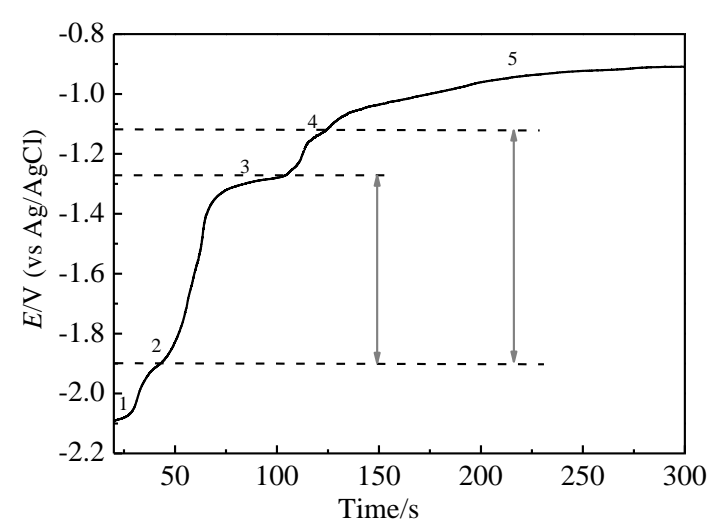

Fig.2 Open circuit transient curve for the $\mathrm{Al}$ electrode after electrodepositing at $-2.20 \mathrm{~V}$ vs. $\mathrm{Ag} / \mathrm{AgCl}$ for $10 \mathrm{~s}$ at $843 \mathrm{~K}$

and diffuses into $\mathrm{Al}$ electrode, the electrode potential gradually shifts to more positive values. During this process, a potential plateau should be observed when the composition of the electrode surface is within a range of two-phase coexisting state ${ }^{[31-36]}$. Therefore, the plateaus 3 and 4 (at about -1.29 and $-1.14 \mathrm{~V}$, respectively) correspond to the mixture of two different $\mathrm{AlCe}_{x}$ alloys.

\subsection{Underpotential deposition of Al-Ce alloys at an Al electrode}

Based on the results of $\mathrm{CV}$ and open-circuit potential, potentiostatic electrolysis was carried out in $\mathrm{LiCl}-\mathrm{KCl}-$ $\mathrm{CeCl}_{3}$ melts on an $\mathrm{Al}$ electrode at $843 \mathrm{~K}$ for $1 \mathrm{~h}$ at $-1.60 \mathrm{~V}$ versus $\mathrm{Ag} / \mathrm{AgCl}$. Fig. 3 shows the XRD pattern of this sample. At this potential, except for Al (PDF\#65-2869), two other peaks are observed as $\mathrm{AlCe}_{3}$ (PDF\#65-1825) and AlCe (PDF\#29-0011). At this electrolytic potential, Ce cannot be electrodeposited but Al-Ce alloys can form on the electrode. Once again it confirms that $\mathrm{Ce}$ (III) can be reduced by UPD.

According to the phase diagram ${ }^{[30]}$ of $\mathrm{Al}-\mathrm{Ce}$, except for $\mathrm{AlCe}_{3}$ and $\mathrm{AlCe}$, the formation temperatures of other Al-Ce alloys are higher than the experimental temperature. Therefore, only two kinds of $\mathrm{AlCe}_{3}$ and $\mathrm{AlCe}$ alloys are obtained under this experimental condition.

The results of XRD patterns accord with open circuit transient curve. The potential plateaus could be considered to correspond to the following two-phase composition and reactions:

Plateau $4(\mathrm{Al}+\mathrm{AlCe})$ :

$$
\mathrm{Al}+\mathrm{Ce}(\mathrm{III})+3 \mathrm{e} \rightarrow \mathrm{AlCe}\left(\Delta E_{1}=770 \mathrm{mV}\right)
$$

Plateau $3\left(\mathrm{AlCe}+\mathrm{AlCe}_{3}\right)$ :

$$
\frac{1}{2} \mathrm{AlCe}+\mathrm{Ce}(\mathrm{III})+3 \mathrm{e} \rightarrow \frac{1}{2} \mathrm{AlCe}_{3} \quad\left(\Delta E_{2}=620 \mathrm{mV}\right)
$$

The formation reactions of $\mathrm{AlCe}$ and $\mathrm{AlCe}_{3}$ are described as the following reactions (2) and (3). Therefore, the standard Gibbs free energies of $\mathrm{AlCe}$ and $\mathrm{AlCe}_{3}$ alloys at $843 \mathrm{~K}$ can be calculated.

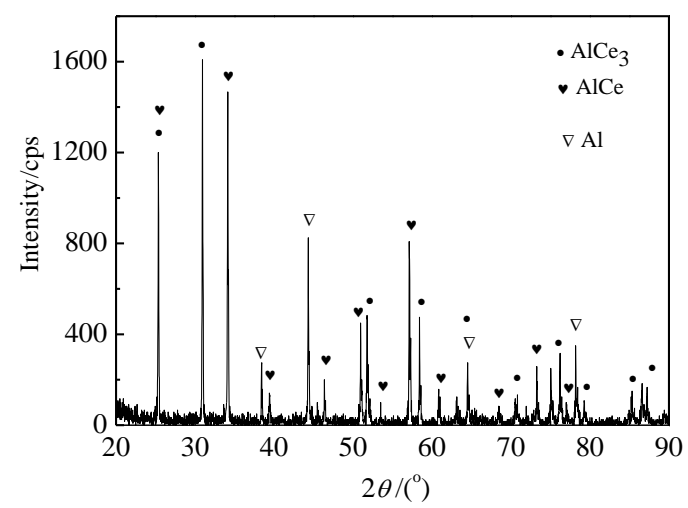

Fig.3 XRD patterns of deposits obtained under potentiostatic electrolysis $(-1.60 \mathrm{~V}$ vs. $\mathrm{Ag} / \mathrm{AgCl})$ at $843 \mathrm{~K}$ for $1 \mathrm{~h}$

$$
\begin{aligned}
& \mathrm{Al}+\mathrm{Ce} \rightarrow \mathrm{AlCe} \\
& \Delta G_{\mathrm{f}(\mathrm{AlCe})}^{\mathrm{o}}=-3 F \Delta E_{1} \\
& \mathrm{Al}+3 \mathrm{Ce} \rightarrow \mathrm{AlCe}_{3} \\
& \Delta G_{\mathrm{f}\left(\mathrm{AlCe}_{3}\right)}^{\mathrm{o}}=2\left(\frac{1}{2} \Delta G_{\mathrm{f}(\mathrm{AlCe})}^{\mathrm{o}}-3 F \Delta E_{2}\right)
\end{aligned}
$$

where, $F$ is faraday constant, then the $\Delta G_{\mathrm{f}(\mathrm{AlCe})}^{\mathrm{o}}$ and $\Delta G_{\mathrm{f}\left(\mathrm{AlCe}_{3}\right)}^{\mathrm{o}}$ are $-222.88 \mathrm{~kJ} \cdot \mathrm{mol}^{-1}$ and $-581.89 \mathrm{~kJ} \cdot \mathrm{mol}^{-1}$ by open circuit chronopotentiometry, respectively.

According to the data ${ }^{[37]}$ of standard heat and standard entropy at $298 \mathrm{~K}$, the calculated standard Gibbs energies of reactions (2) and (3) at $843 \mathrm{~K}$ are calculated to be -155.08 and $-287.18 \mathrm{~kJ} \cdot \mathrm{mol}^{-1}$, respectively, which are smaller than the experimental values. However, based on our knowledge, standard Gibbs free energies of $\mathrm{AlCe}$ and $\mathrm{AlCe}_{3}$ alloys have not been calculated by experimental method so far.

The cross-sections of Al-Ce alloys after potentiostatic electrolysis at $843 \mathrm{~K}$ for $1 \mathrm{~h}$ are presented in Fig.4. A layer of about $28 \mu \mathrm{m}$ in thickness is evenly coated on Al electrode. EDS mapping analysis of element $\mathrm{Ce}$ and $\mathrm{Al}$ are show in Fig.5b and 5c. From the mapping analysis of elements, we can observe that the element cerium mainly disperses homogenously along the surface of the electrode.

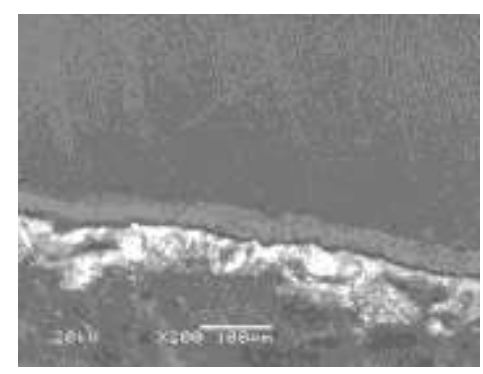

Fig.4 SEM image for Al-Ce alloy by potentiostatic electrolysis $(-1.6 \mathrm{~V}$ vs. $\mathrm{Ag} / \mathrm{AgCl})$ at $843 \mathrm{~K}$ for $1 \mathrm{~h}$ 


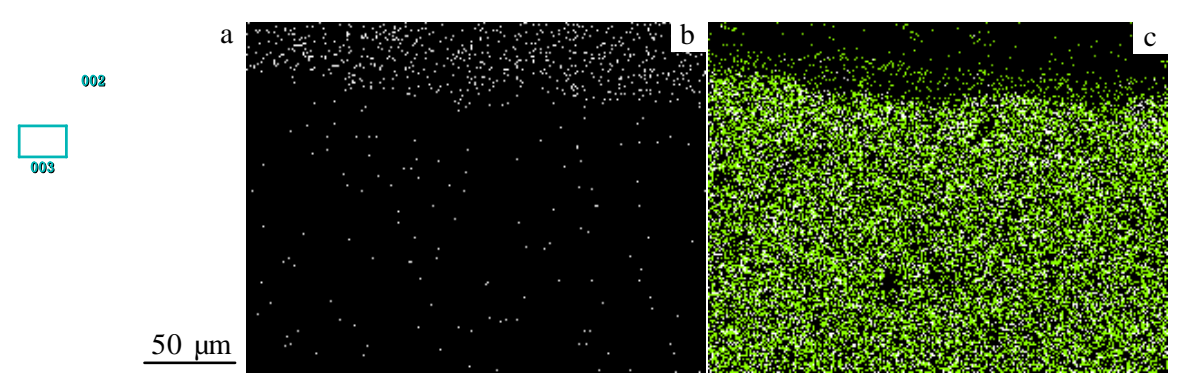

Fig.5 SEM image (a) and EDS mapping analyses of element $\mathrm{Ce}(\mathrm{b})$ and element $\mathrm{Al}$ (c) for Al-Ce alloy by potentiostatic electrolysis ( -1.6 $\mathrm{V}$ vs. $\mathrm{Ag} / \mathrm{AgCl})$ at $843 \mathrm{~K}$ for $1 \mathrm{~h}$
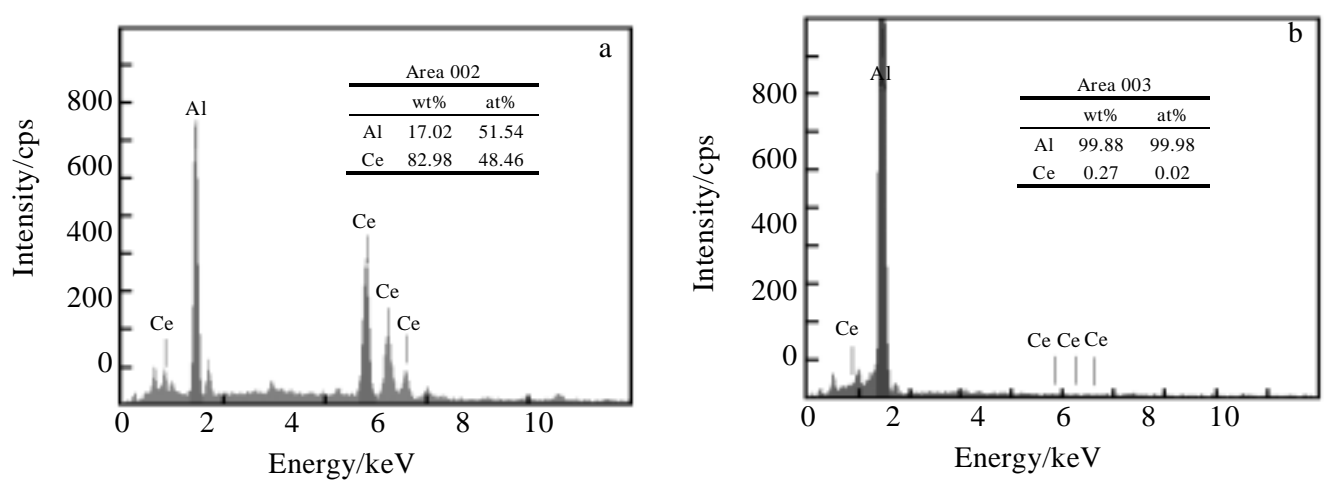

Fig.6 EDS spectra of area 002 (a) and area 003 (b) corresponding to Fig.5a for Al-Ce alloy by potentiostatic electrolysis (-1.6 V vs.

$\mathrm{Ag} / \mathrm{AgCl})$ at $843 \mathrm{~K}$ for $1 \mathrm{~h}$

Fig.6 shows EDS results corresponding to Fig.5a. The areas labeled as 002 and 003 taken from the white zone (the layer) and black zone (the resin), respectively, indicate that the deposit is composed of cerium and aluminum elements. Therefore, the sample prepared by potentiostatic electrolysis is $\mathrm{AlCe}_{x}$ alloys. According to the EDS results, the layer dissolves more $\mathrm{Ce}(82.98 \mathrm{wt} \%$ at area 002) than the resin does $(0.27 \mathrm{wt} \%$ at area 003$)$. Based on the binary phase diagram of Al-Ce system, $\mathrm{Ce}$, as a surface active element, reacts with $\mathrm{Al}$ to form different intermetallic compounds ${ }^{[10]}$. During the solidification process, Al-Ce compounds mainly distribute at the surface of the $\mathrm{Al}$ electrode.

\section{Conclusions}

1) The underpotential deposition of Al-Ce Alloys at an $\mathrm{Al}$ electrode from $\mathrm{LiCl}-\mathrm{KCl}-\mathrm{CeCl}_{3}$ melts can be elucidated by electrochemical methods. The redox potential of the $\mathrm{Ce}(\mathrm{III}) / \mathrm{Ce}$ on $\mathrm{Al}$ active electrode has more positive potential values than those on an Mo electrode. The phenomenon is thermodynamically explained by lowering of cerium activity in the metal phase due to the formation of intermetallic compounds.

2) The Al-Ce alloys are prepared in $\mathrm{LiCl}-\mathrm{KCl}-\mathrm{CeCl}_{3}$ melts at $843 \mathrm{~K}$ by constant potential electrolysis on an $\mathrm{Al}$ electrode. XRD illuminates that $\mathrm{AlCe}$ and $\mathrm{AlCe}_{3}$ are formed. The reasons of formation $\mathrm{AlCe}$ and $\mathrm{AlCe}_{3}$ alloys can be explained by XRD and phase diagram of Al-Ce. The standard Gibbs free energies of formation $\mathrm{AlCe}$ and $\mathrm{AlCe}_{3}$ alloys can be calculated by open circuit chronopotentiometry.

3) The cerium exists at the surface of $\mathrm{Al}$ electrode to form a thickness uniform Al-Ce alloy layer, and the layer of about $28 \mu \mathrm{m}$ in thickness is evenly coated on Al electrode.

\section{References}

1 Liu Kui, Liu Yalan, Yuan Liyong et al. Electrochimica Acta[J], 2013, 109: 732

2 Bermejo M R, de la Rosa F, Barrado E et al. Journal of Electroanalytical Chemistry [J], 2007, 603: 81

3 Taxil P, Massot L, Nourry C et al. Journal of Fluorine Chemistry[J], 2009, 130: 94

4 Liu Yalan, Yuan Liyong, Liu Kui et al. Electrochimica Acta[J], 2014, 120: 369

5 Toda T, Maruyama T, Moritani K et al. Journal of Nuclear Science and Technology[J], 2009, 46: 18

6 Moriyama H, Seshimo T, Moritani K et al. Journal of Alloys and Compounds[J], 1994, 213: 354 
7 Moriyama H, Yamana H, Nishikawa S et al. Journal of Nuclear Materials[J], 1997, 247: 197

8 Mukaiyama T, Takano H, Ogawa T et al. Progress in Nuclear Energy[J], 2002, 40: 403

9 Castrillejo Y, Bermejo M R, Pardo R et al. Journal of Electroanalytical Chemistry[J], 2002, 522(2): 124

10 Cassayre L, Malmbeck R, Masset P et al. Journal of Nuclear Materials[J], 2007, 360: 49

11 Lebedev V A. Selectivity of Liquid Metal Electrodes in Moltenhalides (Title translated)[M]. Russian: 1993: 229

12 Conocar O, Douyere N, Glatz J P et al. Nuclear Science and Engineering[J], 2006, 153: 253

13 Serp J, Allibert M, Le Terrier A et al. Journal of the Electrochemical Society [J], 2005, 152: 167

14 Cassayre L, Soucek P, Mendes E et al. Journal of Nuclear Materials[J], 2011, 414(1): 12

15 Mendes E, Malmbeck R, Nourry C et al. Journal of Nuclear Materials[J], 2012, 420: 424

16 Soucek P, Cassayre L, Eloirdi R et al. Journal of Nuclear Materials[J], 2014, 447: 38

17 Yang Yusheng, Zhang Milin, Han Wei et al. Electrochimica Acta[J], 2014, 118: 150

18 Yan Yongde, Xu Yanlu, Zhang Milin et al. Journal of Nuclear Materials[J], 2013, 433: 152

19 Marsden K C, Pesic B. Journal of the Electrochemical Society[J], 2011, 158(6): 111

20 Betancourtt R, Nattland D. Chemical Physics[J], 2005, 7(1): 173

21 Castrillejo Y, Bermejo M, Millan R et al. Progress in Molten Salt Chemistry $1[\mathrm{M}]$. New York: Elsevier, 2000, 143

22 Iizuka M. Journal of the Electrochemical Society[J], 1998,
145: 84

23 Wang Changshui, Liu Yi, He Hui et al. Journal of Rare Earths[J], 2013, 31(4): 405

24 Fusselman S P, Roy J, Grimmett D et al. Journal of the Electrochemical Society [J], 1999, 146(7): 2573

25 Lantelme F, Cartailler T, Berghoute Y et al. Journal of the Electrochemical Society[J], 2001, 148(9): 604

26 Zhang Meng, Han Wei, Zhang Milin et al. Journal Rare Earths[J], 2013, 31(6): 609

27 Kim T, Ahn D H, Paek et al. International Journal of the Electrochemical Science [J], 2013, 8: 9180

28 Zhang Meng, Han Wei, Zhang Milin et al. Chemical Research in Chinese Universities[J], 2014, 30(3): 489

29 Castrillejo Y, Bermejo R, Martı'nez A M et al. Journal of Nuclear Materials[J], 2007, 360: 32

30 Buschow K H J, Van Vucht J H N. Philips Res Rep[J], 1967, 22: 233

31 Iizukaa M, Inouea T, Shiraib O et al. Journal of Nuclear Materials[J], 2001, 297: 143

32 Wei Shuquan, Zhang Milin, Han Wei et al. Electrochim Acta[J], 2011, 56: 4159

33 Konishi H, Nishikiori T, Nohira $\mathrm{T}$ et al. Electrochimica Acta[J], 2003, 48: 1403

34 Nohira $\mathrm{T}$, Kambara $\mathrm{H}$, Amezawa $\mathrm{K}$ et al. Journal of the Electrochemical Society [J], 2005, 152: 183

35 Bermejo M R, Barrado E, Martínez A M et al. Journal of Electroanalytical Chemistry[J], 2008, 617(1): 85

36 Yan Yongde, Tang Hao, Zhang Milin et al. Electrochimica Acta[J], 2012, 59: 531

37 Kang Y B, Pelton A D, Patrice C et al. Computer Coupling of Phase Diagrams and Thermochemistry[J], 2008, 32: 413

\title{
在 $\mathrm{LiCl}-\mathrm{KCl}-\mathrm{CeCl}_{3}$ 熔盐中铝电极上欠电位沉积制备 $\mathrm{Al}-\mathrm{Ce}$ 合金
}

\author{
张 萌 ${ }^{1,2}$, 李云娜 ${ }^{2}$, 韩 伟 $^{2}$, 张密林 ${ }^{2}$, 薛 云 $^{1,2}$, 王艳力 ${ }^{2}$, 高 杨 $^{1}$ \\ (1. 哈尔滨工程大学 核安全与仿真技术国防重点学科实验室, 黑龙江 哈尔滨 150001) \\ (2. 哈尔滨工程大学 超轻材料与表面技术教育部重点实验室, 黑龙江 哈尔滨 150001)
}

\begin{abstract}
摘 要: 在 $843 \mathrm{~K} \mathrm{LiCl}-\mathrm{KCl}-\mathrm{CeCl}_{3}$ 熔盐中活性铝电极上, 研究了 $\mathrm{Ce}(\mathrm{III})$ 离子的电化学行为和欠电位沉积 $\mathrm{Al}-\mathrm{Ce}$ 合金。对比循环伏安曲 线发现, 在 $\mathrm{Al}$ 电极上 $\mathrm{Ce}(\mathrm{III}) / \mathrm{Ce}$ 反应的氧化还原电势比在 $\mathrm{Mo}$ 惰性电极上更正; 开路计时电位在金属铝和铈的沉积平台之间出现 2 个 平台, 这表明 $\mathrm{Ce}(\mathrm{III})$ 在 $\mathrm{Al}$ 活性电极上可以生成两种金属间化合物。以上结果在电化学机理上说明 $\mathrm{Ce}(\mathrm{III})$ 离子可以在 $\mathrm{Al}$ 电极上欠电位 沉积形成金属间化合物。在该实验条件下通过恒电位电解，在 $\mathrm{Al}$ 电极上得到了 $\mathrm{Al}-\mathrm{Ce}$ 合金，验证了电化学分析的结果。经 XRD 表征， 证实形成了 $\mathrm{AlCe}$ 和 $\mathrm{AlCe}_{3}$ 两种合金, 结合 $\mathrm{Al}-\mathrm{Ce}$ 合金相图分析了只产生这两种合金的原因; 结合开路电位计算了生成这两种合金的标 准吉布斯自由能变值。经 SEM 和 EDS 表征, 证明了铈在 $\mathrm{Al}$ 电极表面分布, 并形成厚度均一约 $28 \mu \mathrm{m}$ 的 $\mathrm{Al}-\mathrm{Ce}$ 合金镀层。
\end{abstract}

关键词： $\mathrm{LiCl}-\mathrm{KCl}$ 熔盐; 欠电位沉积; 铝电极; $\mathrm{Al}-\mathrm{Ce}$ 合金

作者简介: 张 萌, 女, 1980 年生, 博士, 副教授, 哈尔滨工程大学核科学与技术学院, 黑龙江 哈尔滨 150001, 电话: 0451-82519702, E-mail: happymeng1980@126.com 